\title{
Unit per Kilogram per Day
}

National Cancer Institute

\section{Source}

National Cancer Institute. Unit per Kilogram per Day. NCI Thesaurus. Code C73777.

An arbitrary unit of substance rate expressed in unit(s) per kilogram per period of time equal to twenty-four hours. 